(I) that the irregularities are not in the band itself, but are due to a number of real, grey spots which are left isolated by the retreat of the disappearing cap; (2) that the distance of the dark band from the edge of the cap is too great to be covered by the "spreading" of the image of the latter. Further, he continues, if the phenomenon of the dark band is real, it should obey the ordinary laws of perspective, and should appear about two and a quarter times as broad at the extremities of the major axis of the projected cap as it does at the ends of the minor axis; but the majority of drawings show the band to be the same width all round, and $M$. Antoniadi therefore contends that it is a subjective effect produced by contrast.

Temperature Classification of Stars.--In No. 4375 of the Astronomische Nachrichten Drs. Wilsing and Scheiner publish a list of 109 bright stars of which they have determined the effective temperatures by spectral photometric observations. The temperatures determined range from $2800^{\circ}$ (absolute) for $\chi$ Serpentis, to $12,800^{\circ}$ for $\lambda$ Orionis, and, in a summary, the range from Vogel's type I $a_{\mathrm{I}}$ to type III. is given as $9600^{\circ}-3200^{\circ}$.

Dr. Nordmann, also, has recently published several rotes, in the Comptes rendus, giving the results obtained by his method of photometric comparisons of various definite regions of the spectra. In No. 4 he gave a list of fifteen temperatures ranging from $2870^{\circ}$ to $>60,000^{\circ}$ (absolute), and compared the order in which the stars were thus arranged with the order given, for the same stars, in Sir Norman Lockyer's temperature classification. The latter, of course, does not deal with actual temperatures, but in general the two arrangements were found to agree fairly well; Dr. Nordmann's value for the solar temperature also agrees well with the values determined by previous observers. In a later note confirmation of the temperature given for Algol was obtained by an independent method, whilst in the most recent publication (Comptes rendus, No. 23, December 26) Dr. Nordmann gives amended values of the temperatures primarily published. The only important alterations are found towards the upper temperature limit, and do not involve any rearrangement of the sequence; the highest temperature (for $\lambda$ Tauri) is now given as $>40,000^{\circ}$.

A New Variable Star, or a Nova.-In No. 4275 of the Astronomische Nachrichten Prof. Ceraski announces that o'l a plate taken on March 23, at Ioh. $6 \mathrm{~m}$. to $12 \mathrm{~h} .6 \mathrm{~m}$. (M.T. Moscow), Madame Ceraski discovered an image of a tenth-magnitude object which is absent from twenty-four earlier plates, showing $\mathbf{1 2 . 5}$ magnitude stars, of the same region. The approximate position of this object is 8h. $29 \mathrm{~m} .26 \mathrm{~s}$., $+53^{\circ} 5 \mathrm{o}^{\prime}$ (1900), and the shape of the image shows it to be a star; the suggested explanations that it might be a planet or an end-on meteor are thought to be improbable, and Prof. Ceraski suggests that all observers having plates of this region should examine them for traces of what may be either a nova or a new variable star.

The "Companion to the Observatory."-Edited by Messrs. T. Lewis and H. P. Hollis, and published, at Is. $6 d$., by Messrs. Taylor and Francis, this annual is the most generally useful, to the practical, general astronomer, of all the British annual publications. The issue for I9Io differs but little in form from its immediate predecessors, the usual contributions having been obtained from $\mathrm{Mr}$. Denning, Dr. Maw, Mr. Crommelin, and M. Baillaud.

\section{THE RELATION OF SCIENCE TO HIUMAN} \section{LIFE.}

$\mathrm{I}^{\mathrm{N}}$ casting about for a suitable introduction for my written by a great Englishman, which with your permission I will read to you.

"Remember the wise; for they have laboured, and you are entering into their labours. Every lesson which you learnt in school, all knowledge which raises you above the savage and the profligate-who is but a savage dressed in civilised garments-has been made possible to you by the wise. Every doctrine of theology, every maxim of

${ }^{1}$ Address delivered at the Imperial C lllege of Science and Technology on December 56 by Prof. A. Sedgwick. F R.S.

NO. 2095, VOL. 82] morals, every rule of grammar, every process of mathematics, every law of physical science, every fact of history or of geography, which you are taught, is a voice from beyond the tomb. Either the knowledge itself, or other knowledge which led to it, is an heirloom to you from men whose bodies are now mouldering in the dust, but whose spirits live for ever and whose works follow them, going on, generation after generation, upon the path which they trod while they were upon earth, the path of usefulness, as lights to the steps of youth and ignorance.

"They are the salt of the earth, which keeps the world of man from decaying back into barbarism. They are the children of light. They are the aristocracy of God, into which not many noble, not many rich, not many mighty, are called. Most of them were poor; many all but unknown in their own time; many died and saw no fruit of their labours; some were persecuted, some were slain, as heretics, innovators and corruptors of youth. Of some the very names are forgotten. But though their names be dead, their works live, and grow and spread over ever fresh generations of youth; showing them fresh steps towards that temple of wisdom which is the knowledge of things as they are; the knowledge of those eternal laws by which God governs the heavens and the earth, things temporal and eternal, physical and spiritual, seen and unseen, from the rise and fall of mighty nations to the growth and death of moss on yonder moors."

So spake Charles Kingsley, and his words I make use of as an introduction which strikes the key-note of what I have to say to you to-day.

The subject which I have chosen for my address-the relation of pure science, and especially of biological science, to human life, and inferentially the relation which ought to exist between pure and applied science in a college of science--is naturally of great interest to us in the Imperial College, which is a college of science and technology, and the purposes of which are, in the words of the charter, " to give the highest specialised instruction and to provide the fullest equipment for the most advanced training and research in various branches of science, especially in relation to industry." Particularly do I desire to set forth as clearly as $\bar{I}$ can the justification for including in a college which deals, not only with science, but with science in relation to industry, those branches of science which deal with organisms.

As industry forms the principal occupation of human life, and as the phenomena of organisms constitute the science of life, it may seem absurd to set out solemnly to justify the inclusion of the biological sciences in a college which deals with science especially in its relation to human life. Nevertheless, having regard to the fact that I have heard some doubt expressed as to whether the cult of the biological sciences properly falls within the scope of the Imperial College, it may not be out of place to bear the matter in mind on this, the second, occasion of the prizegiving of our new college.

What is the meaning of the word science? As in the case of so many words, its meaning has become confused by its partial application, i.e. by its application to a part only of its contents, and this has often led to a misapprehension of the relation of science and of the scientific man to life. Science simply means knowledge, and to speak of scientific knowledge, as opposed to ordinarv knowledge, is to use a redundant phrase, always supposing that we are using the word knowledge in its strict sense. Huxley defined science as organised common sense, by which, I take it, he meant knowledge of things as they are-knowledge the reality of which can at any time be checked by observation and experiment; for common sense, if it is anything, is the faculty by which we are made aware of reality. Science is sometimes spoken of as exact knowledge, but $I$ am bound to say that I do not like the phrase exact knowleage; it seems to imply an insult to the word knowledge. Its use reminds me of a friend of mine who, when he was offered one morning at breakfast a fresh egs, milály asked, "In preference to what other kind of egg?" It recalls those regrettable phrases one so often hears, I honestly believe, or I honestly think; one wonders how the people who make use of them usually believe and think.

It must, I think, be admitted that science simply means 
knowledge, and that there is nothing peculiar about the knowledge of scientific men by which it differs from other knowledge.

Scientific men are not a class apart and distinct from ordinary mortals. We are all scientific men in our various degrees. If this is so, how comes it that the distinction is so often made between scientific men and non-scientific ren, between scientific, knowledge and non-scientific knowledge? The truth appears to lie here: though it is true that all men possess knowledge, i.e. science, yet there are some men who make it their main business to concern themselves with some kind of knowledge, and especially with its increase, and to these men the term scientific has been technically applied. Now the distinctive feature of these men, in virtue of which the term scientific is applied t. them, is that they not only possess knowledge, but that they make it their business to add to knowledge, and it is this part of their business, if any, which justifies their being placed in a class apart from other possessors of knowledge.

The men who make it their main business to add to knowledge may be divided into two classes, according to the motive which spurs them on. (I) There are those whose immediate object is to ameliorate the conditions of human life and to add to its pleasures; their motive is utility, and their immediate goal is within sight. Such are the great host of inventors, the pioneers in agriculture, in hygiene, preventive medicine, in social reform and in sound legislation which leads to social reform, and many other subjects. (2) There are those who pursue knowledge for its own sake without reference to its practical application. They are urged on by the desire to know, by what has been called a divine curiosity. These men are the real pioncers of knowledge. It is their work which prepares the way for the practical man who watches and follows them. Without their apparently useless investigations, progress beyond the limits of the immediately useful would be impossible. We should have had no applied electricity, no spectrum analysis, no aseptic surgery, no preventive medicine, no anæsthetics, no navigation of the pathless ocean. Sometimes the results of the seeker after knowledge for its own sake are so unique and astounding that the whole of mankind stands spellbound before them, and renders them the same homage that the child does the tale of wonderful adventure; such is the case with the work on radium and radio-activity, which is at present fixing the attention of the whole civilised world. Sometimes the work is of a humbler kind, dealing apparently with trivial objects, and appealing in no way to the imagination or sense of the wonderful; such was the work which led to and formed the basis of that great generalisation which has transformed man's outlook on nature-the theory of organic evolution; such was the work which produced aseptic surgery and the great doctrines of immunity and phagocytosis which have had such tremendous results in diminishing human pain. The temper of such men is a curious one; no material reward can be theirs, and, as a rule, but little fame. Yet man. kind owes them a debt which can never be repaid. It is to these men that the word scientific has been specially applied, and with this justification-they have no other profession save that of pursuing knowledge for its own sake, or, if they have a profession, it is that of the teacher, which, indeed, they can hardly avoid. Ought such men. working with such obiects, to find a place in the Imperial College?

It is a curious thing, but it has only comparatively recently been realised, that a sound and exact knowledge of phenomena was necessary for man. The realisation of this fact, in the modern world at any rate, occurred at the end of the Middle Ages; it was one of the intellectual products of the Renaissance, and in this country Francis Bacon was its first exponent. In his "Advancement of Icearning " he explained the methods by which the increase of knowledge was possible, and advocated the promotion of knowledge to a new and influential position in the organisation of human society. In Italy the same idea was taught by the great philosopher Giordano Bruno, who held that the whole universe was a vast mechanism of which man, and the earth on which man dwells, was a portion, and that the working of this mechanism, though NO. 2095, VOL. 82] not the full comprehension of it, was open to the investigation of man. For promulgating this impious view both he and his book were burnt at kome in I6oo. You will find the same idea cropping up continually in the written records of that time; Copernicus gave it practical recognition when he demonstrated the real relation of the earth to the sun, and it was thoroughly grasped by our own Shakespeare, who gave it expression in the dialogue between Perdita and Polixines in the Winter's Tale:-

\section{Perdita. 'The fairest flowers o' the season}

Are our carnations and streaked gillyvors,

Which some call Nature's bastards: of that kind

Our rustic garden's barren; and I care not

To get slips of them.

Polixines. Wherefore, gentle maiden, do you neglect them?

Perdita. For I have heard it said

There is an art which, in their piedness, shares

With great creating nature.

Polixines.

Say there be;

Yet nature is made better by no mean,

But nature makes that mean: so, o'er that art

Which you say adds to nature, is an art

That nature makes. You see, sweet maid, we marry

A gentle scion to the wildest stock and make conceive a bark of baser kind

By bud of nobler race: this is an art

Which does mend nature,--change it rather; but

The art itself is nature.

It is not dificult for us, though it may be difficult to our descendants, to understand how hard it was for man to attune himself to this new, this mighty conception, and the intellectual history of the last three hundred years is a record of the struggles to make it prevail.

Trained through long ages to believe that the heavens were the abode of the gods, who constantly interfered in the daily affairs of life and in the smallest operation of nature, it seemed to men impious to maintain that the earth was in the heavens, and to peer into the mysteries which surrounded them, and the endeavour to do so has been stoutly resisted; but the conflict, in so far as it has been a conflict with prejudice, is now over. It vanished in the triumph of the modern views on the origin of man which will be for ever associated with the names of Lamarck, Spencer, and Darwin.

The triumph of these views does not mean that they are correct or that we know anything more about the great mystery of life than we did before. He would be a bold and a prejudiced man who made that assertion. What it means is this, that man is grown up, that he has cast off the intellectual tutelage under which he has hitherto existed, that he has attained complete intellectual freedom, and that all things in heaven and earth are legitimate subjects of investigation. But it means even more than this; it means that the conviction is rapidly growing upor him that the only way in which he can hope to improve his condition is by understanding the laws, physical as well as spiritual, under which he exists, and this he is determined to try to do by the only method open to him-that of minute and arduous research.

And is it, I ask, an unworthy ambition for man to set before himself to understand those eternal laws upon which his happiness, his prosperity, his very existence depend? Is he to be blamed and anathematised for endeavouring to fulfil the divine injunction, Fear God and keep His Commandments, for that is the whole duty of man? Before he can keep them, surely he must first ascertain what they are!

We hear a great deal nowadays about the humanities and the humane studies-the study of "ancient elegance and historic wisdom"--and I should be the last to minimise in any degree the value and intense interest which is attached to the study of the writings and utterances of the mighty dead. They will always retain undimmed their attraction and inspiration for man, and man will always think with gratitude and affection of their authors; but it is possible to overdo a thing, and this talk of the humanities and humane studies has been overdone. After all, a live dog is better than a dead lion-but in this case we are dealing with a living lion. 
It is ridiculous to say nowadays that the study of the humanities consists solely of the study of the writings and philosophy of the ancients; to take that view is to take the view of the schoolmen, the death-blow to which was given by Bacon and Bruno.

We have got beyond that; we claim that the true study of the humanities is a far wider thing-it is the study of the stupendous mechanism of the universe of which man forms a part, and the understanding of which is necessary for his happiness. That is the true humanity of which the other forms only a small portion. The time is coming when the principal preoccupation of man shall be the gradual disclosure of this mechanism and his principal delight the contemplation of its beauty. For remember what Plato himself said: the whole of nature, so far as it really exists, is a revelation of God.

In spite of the work and writings of such men as Bacon and Bruno in the end of the sixteenth century, the progress of science was at first but slow and the workers few. We have, of course, the immortal achievements of Newton and Harvey, and the foundation of the Royal Society, and the tremendous outburst of scholarship as typified in this country by Bentley and his co-workers; but the eighteenth century was, on the whole, characterised by intellectual quiescence both in scientific output and in literary creation. The quiescence was apparent rather than real. To borrow a metaphor from the garden, though there was little growth above ground, active root formation was going on. Linnæus (1707-78) was at work in Sweden creating the framework which rendered future work in botany and zoology possible; Buffon in France was cautiously feeling his way towards a theory of organic evolution; Henry Cavendish (1731-1810), Joseph Priestley (I733-1804), and Antoine Lavoisier (1743-94) were laying the foundations of modern chemistry; Albrecht von Haller (1;07-77), Kaspar Friederick Wolff '(r733-94), and John Hunter (1728-93), those of anatomy and physiology. The spade-work of these men, together with the improvement of the microscope, was necessary for the great outburst of scientific investigation which characterised the nineteenth century. Ushered in by the work of Cuvier ( $\left.1769-13_{32}\right)$, I, amarck (1744-1829), St. Hilaire (1772-1844), in biology, Thomas Young (1773-1829), Laplace (1749-1827), Volta ( $1745^{-1827)}$, Carnot ( $175^{8-1823), ~ i n ~ p h y s i c s, ~ i t ~ w a s ~ a d o r n e d ~}$ in its middle and latter period by the names of Davy, Faraday, Dalton, Arago, Richard Owen, Darwin, Lyell, Joh. Müller, Agassiz, Helmholtz, Stokes, Kelvin, and Pasteur.

The advance of knowledge is yearly becoming more rapid; if its steps were slow and hesitating in the seventeenth and eighteenth centuries, and if it quickened to a rapid walk in the nineteenth, we now hear the sound of a trot, which at the end of the century will be a gallop, and as the centuries succeed one another its pace will become even faster. Where will it lead us, and what will be the upshot for man?

But it is no part of my purpose to-day to give you an historical summary of scientific progress. The point I wish to illustrate is the vast increase in the scientific army and in the results achieved by them.

My thesis is that pure research into the sequence of natural phenomena is in itself of the greatest importance to the progress and welfare of humanity, and that a great statesman can have no higher aim than to solve the problem of how it may best be fostered. To what extent can such a thesis be justified by experience?

I might begin by examining the origin and progress of our knowledge of what is called current electricity, to which modern life, from a material point of view, owes so much. In illustration of what we owe to workers in electrical science I need only mention land telegraphy, ocean telegraphy, wireless telegraphy, telephones, electric light, electric traction, and our knowledge of radio-activity. The history of this science forms, perhaps, the best example of the importance to man of pure, apparently useiess, scientific research, for at every stage of it, from Galvani's original observation through the discoveries of the Swede Oersted and of the Frenchman Ampère to those of our own Faraday and to the theoretical adumbrations of Clerk Maxwell and to the researches of Crookes on the Fassage of electricity through vacuum tubes, we meet with the investigation of phenomena which were apparently perfectly useless, and which to most practical men must at the time they were made have appeared as little more than scientific toys provided by nature for the harmless amusement of the queer people who meet in the rooms of the Royal Society and suchlike places where unpractical oddities resort. And yet I ask you to reflect upon the astounding results which have arisen from Galvani's observations made to discover the cause of the twitching of the frog's legs, and of Faraday's discovery of induction, and to indulge your imaginations in an endeavour to predict what may issue for man from Crookes's investigations of the glow without heat of the vacuum tubes.

But I have neither the knowledge nor the time to dwell upon the physical side of science. As in private duty bound, I must devote the short time at my disposal to examples culled from the biological sciences.

The great Frenchman Pasteur, in making a thorough examination of the process by which alcohol was obtained from sugar, discovered the part played by the organism known as yeast, and established the idea of organised ferment bodies. He extended his observations to other micro-organisms, and, in conjunction with his co-workers, among whom must be included those who were looking into the question of the spontaneous generation of living matter, definiteiy gave us the idea that putrefaction was caused by micro-organisms acting upon organic matter, that these micro-organisms are capable of resisting drought; and when dried float freely in the air and are distributed everywhere. When they fall upon a suitable material their vital activity is resumed, and they increase with incredible rapidity and set up putrefaction. It was reserved for our distinguished countryman Lister, then a surgeon in Edinburgh, to recognise the importance of these discoveries for surgery. Knowing of the researches of Pasteur and his fellow-workers, he conceived the idea that suppuration was due to putrefaction in the organic matter of the wounds caused by micro-organisms. Acting on this, he introduced his method of antiseptic surgery, by which his name has been rendered immortal. I think we may say that no single application of the results of pure research has done more to preserve human life and to diminish human suffering than this linking up by Lister of the putrefaction of suppuration with the work of his predecessors on the effects of the actions of micro-organisms upon organic matter. It is well to notice, in passing, that this discovery of Lord Lister's is a good illustration of the difficulty. which the human mind has of conceiving even the simplest new idea. To us, now, how simple seems the step which Lister made; yet there were thousands of surgeons in the world who failed to make it, though they were continually dealing with suppurating wounds and wondering why they suppurated, and when it was made it was stoutly discredited by many quite able men.

I must now turn to another subject which is closely connected with the preceding, and well illustrates my thesis that pure scientific research, without reference to practical utility, is of the highest importance to mankind.

It will doubtless have occurred to many of you to ask the question, How is it, if the air contains foating in it the dried spores of multitudinous micro-organisms which only need a suitable medium for their development and increase, how is it that they do not obtain a lodgment in the healthy animal body, which one would think offers all the conditions necessary to their growth? It can easily be shown that the air we breathe, the water we drink, the food we eat, everything that we touch, swarms with these microscopic creatures; that they enter our lungs, that they germinate in our skin, that they occur in count. less numbers in our alimentary canals, in short, that they are found everywhere on our body surfaces. How is it that they do not increase and turn our organs into a seething mass of putrefying corruption? One would expect that even if the skin and the membrane bounding the internal organs to which they obtain entrance incurred the slightest lesion, even a pin-prick, that they would have been able to enter. We know that after death they at once obtain complete dominion, and we therefore infer that in life there must be some protective mechanism in the body capable of dealing with them.

NO. 2095, VOL. 82] 
The discovery that there is such a mechanism was made in the early 'eighties by the distinguished Russian zoologist Elias Metschnikoff, though the need of its existence was not recognised by biologists in general until later. The result of this was that his remarkable discoveries were at first pooh-poohed and discredited by many, but ultimately they gained acceptance, and their further development in his own hand and that of others has wrought a revolution in the art of preventive medicine.

The mechanism consists of the small amœboid cells found in the blood, lymph, and body fluids generally, and called leucocytes, or white blood corpuscles. Though long known to exist, very little had been ascertained as to their function until Metschnikoff, working at such remote subjects as the embryology of sponges, the structure and digestion of polyps, the blood of water-fleas, realised that these small amoba-like cells, which exist in all organisms, actually swallow, digest, and so destroy small foreign bodies which have invaded the organisms. He called them the phagocytes, and all his subsequent work has been directed to the elucidation of their mode of action.

It is to Metschnikoff's work, prompted solely by the scientific spirit, that we owe our knowledge of phagocytosis and the great theory of immunity which has proceeded from it. It is impossible at the present moment to estimate fully the value to man of Metschnikoff's discoveries. Suffice it to say that they have already led to important practical results, and have revolutionised treatment.

I must now turn for a moment to another subject of the greatest importance to mankind, and one which has been brought into notice by the researches, perfectly useless so far as our material welfare is concerned, which were undertalken with the view of elucidating the great question of organic evolution. I refer to the study of genetics, which deals with the question mainly of the transmission of the properties of the organism; but it deals with even a larger subject than that. It looks into and tries to determine the laws which govern the origin of the characters of individuals, whether plants or animals, whether those characters have been acquired by inheritance or in some other way. The subject is of the utmost interest and practical importance to man from three points of view. It has a bearing on philosophy of a most important and far-reaching kind through the theory of organic evolution. That theory largely depends for its proof upon the science of genetics. Secondly, it has a most important bearing upon practical questions affecting breeders of animals and raisers of plants, and also upon man himself in connection with practical legislation. This brings me to the third point, in which this subject specially appeals to us, and that is what I may call its bearing upon ethics. This is, of course, closely connected with the last.

We are constantly confronted with questions in which we have to think, not only of the advantage and happiness of those alive at the present moment, but also of these not yet born who will succeed us on the earth. The decision of these questions is one of the most important and burning subjects which can be put before us. They often crop up in legislation, and yet we are quite unable to answer them because of the very little knowledge we possess of the laws which govern the transmission of characters from generation to generation.

The interests of future generations often appear to be in conflict with the immediate pleasure and happiness of the living, and we are confronted with the question whether we ought to give way to our own humane and benevolent feelings or whether we ought to set our teeth and deal ruthlessly with a number of people who nust appeal to our pity, lest by saving them from elimination we should bring about an increase in the number of people who are unable to hold their own, and so weaken the nation and increase for the next generation the difficulties which we set out to cure. I do not pronounce any judgment on these questions: I merely wish to emphasise the immense, the transcendent importance, from the human point of view, of the investigations which the study of the question of evolution has caused biologists to carry out into that most difficult of all subiects, heredity, and of obtaining clear ideas upon the subject. These, I admit, are elementary examples, and probably familiar to most of you-and they NO. 250.5, VOL. 82] might be largely added to from other branches of zoology, such as entomology, marine fauna, and physiology-of the great practical achievements which have followed from the recognition of the fact, possibly appreciated in some ancient civilisations, ${ }^{1}$ but in modern times first understood by Bacon and his compeers, that natural phenomena are in themselves, and without reference to immediate utility, proper subjects of man's inquiry, and that all progress must be based on their thorough and accurate investigation.

'The genesis of a new idea is so difficult, and the amount of work necessary for its complete elucidation and development so vast and detailed, that many eminent men, taking only a short period of time and not realising the minute steps by which the advance of knowledge takes place, have been led to doubt the value of scientific investigation in the higher realms of pure knowledge, even to the extent of speaking of the bankruptcy of science. Others, again, perceiving the apparent aimlessness of many investigations and undervaluing the motive which urges them on, have cone to look with a certain contempt upon the man of pure science and his slow and plodding progress. What is the good of all this work at unimportant details? What do you get out of it, and what pleasure do you find in it? they ask, and when they are told that the humble worker usually gets nothing out of his work except the pleasure of doing it, and that his motive is nothing more elevated than the satisfaction of his curiosity, there does appear to be, it must be admitted, some justification for the contemptuous indifference with which the poor researcher is regarded by a considerable section of the population, as is shown by the almost entire absence of support of pure scientific research on the part of the Government. With the exception of an annual grant of $4000 l$. a year given to the Royal Society, I think I am correct in stating that the Government affords hardly any support to science save to such as is concerned with teaching or with some practical problem; and when one remembers the composition of Governments and the manner in which, and the reasons for which, they are chosen, one cannot unreservedly blame them for this attitude. The best method of fostering research is a difficult problem, and I can well understand that a modern democratic Government, depending as it does upon popular support with its attendant popular mandates, should shrink from dealing with it. To do so would bring them no popularity and no votes, and too often they are not really aware of its immense importance to human progress, and when they are they have great difficulties to face.

For it is impossible to organise research on a commercial basis. "All attempts," says Prof. Nichols, of Cornell, " at a machine-made science are doomed to failure. No autocratic organisation is favourable to the development of the Scientific Spirit. No institution after the commercial models of tc-day is likely to be generously fertile. You can contract for a bridge according to specifications. No one, however, can draw up specifications for a scientific discovery. No one can contract to deliver it on a specific day for a specified price, and no employee can be hired to produce it for wages received."

This it is impossible to get the public to understand even when it has undergone the process which we call education. You may establish paid posts for scientific research, but you cannot be sure that you will get research, for science is like the wind that bloweth where it listeth, and that is what our educated public do not like. They want something for their cash, and they will not wait.

Even those who are aware of the immense value of pure research forget the fact that the aptitude for scientific investigation is as rare as the gift of poetry, to which in many respects it is allied, for both are creative gifts, rare and precious. They forget that it is impossible to ascertain without trial whether a man possesses it or not, and that this trial can only be made when he has passed his student days and looks to support himself by his own

1 There are, as is well known, indications that research into natural phenomena was rractised and esteemed in some ancient civilisations which have been destroyed ty the inroad of barbarians or by orher causes. One bnoks of the Hindus of these indications is the record in one of the sacred ably much nlder, that malarial fevers less than 1400 years old, and is probably much nlder, that malarial fevers are directly caused bv the hite of mos-
guitoes. Attention was first diected to this record bv Sir $\mathrm{H}$. A Guitoes. Attention was first diected to this record bv Sir H A. Blake, Ceylon Branch of the British Medical Association, vol. ii., part i., 2905). 
exertions. To provide for this support money is needed, and studentships must be established in considerable numbers, from the holders of which those who show that they possess the gift of research can be selected and promoted to higher posts in which their gift can find full opportunity; but we want more than this-we want compensation for those whom we have encouraged to make the trial and who have failed to show that they possess the gift, and an outlet by which they can emerge and find work in practical life.

This has been and is a difficulty in all schools of science, for many are called but few are chosen. The situation is this : it is desirable that a large body of able young men should be encouraged to take up scientific research, but as experience has shown that only a small proportion of them will possess the qualities by which success in research can be attained, and as it is undesirable to encumber the progress and the literature of science by a host of workers who have no real capacity for research, it results that a time will arrive when a great proportion of those whom we have encouraged to give some of the best years of their life to this unremunerative work should be invited to find other occupations. What is to be done? We cannot throw them into the street. Some compensation must be given. There are two ways in which this can be done. One is the system of prize fellowships, which has for long been in vogue at the uld universities, and which it has of late been the custom of those who have not really studied the matter to decry. Nevertheless, it is a good system, for it provides an income by which those who have given some of the best years of their life to this trial of their capacity can support themselves while they qualify for taking part in a practical profession.

A prize fellowship system, or something like it, is a necessary accompaniment of a university which induces a large number of young men to follow for a time the intellectual life; it acts both as an inducement and a compensation, and it would be a mistake and an injustice, in my opinion, to abolish it; but there is another way in which the difficulty can be met, and that is the way which has been adopted by the wise and far-seeing founders of the Imperial College, namely, by the combination of a school of science with a school of technology. If you have incorporated in your school of science a school of applied science, and if you at the same time take care that none but able men are allowed to enter the research grade, and if you establish, as you niust do if you honestly work your school, a connection with the great industrial interest of the country, you have all that is necessary for the disposal of those men who, for whatever reason, find themselves unable to follow a life of pure science. As is well known, the faculty for pure, apparently useless, research in science is often possessed by men without any aptitude for practical application of science or desire of practical success and the wealth which practical success brings, while, on the contrary, many minds of the highest order cannot work at all without the stimulus of the thought of the practical outcome of their labour.

In our college there is room both for those with the highest gifts for pure scientific research and for those with the inventive faculty so inportant in the arts, or with the knowledge and ability for controlling and organising great industrial enterprises; and, what is more, the combination of the two types of mind in the same school cannot but be of the greatest advantage to both, not only on account of the atmosphere which will be created, so favourable to inteilectual effort, but also because good must result from the contact in one school of minds whose ulti mate aim is to probe the mysteries of nature and to acquire control over her forces.

As Prof. Nichols has well said in pointing out the depencience of technology on science :- "The History of Technology shows that the essential condition under which useful applications are likely to originate is Scientific proructiveness. A country that has many investigators will have many inventors also. . . . Where science is, there will its by-product technology be also. Communities having the most thorough fundamental knowledge of pure science will show the greatest output of really practical inventions. Peoples who get their knowledge at second hand must be ccntent to follow. Where sound scientific conceptions are NO. 2095, VOL. 82] the common property of a nation, the wasteful efforts of the half-informed will be least prevalent." These are sound conclusions, and experience has shown that if the terms are interchanged the same remarks may be made with equal truth of the good influence which results to a school of science from its association with a school of technology.

Before concluding, it may be well to say a word as to the origin of the great imperial institution in the interests of which we are met here to-day. It may justly be described as the natural and necessary outcome of the scheme for scientific instruction which was originated by that great Prince whose memorial stands near the end of Exhibition Road, and to whom science and art in England owe so much. He dreamed a dream which his untimely death alone prevented him from realising. Had he lived, who can set a bound to what he would have achieved for science and education in England? It is a most happy circumstance that the final stages of the realisation of that dream should have been entered upon in the reign, and have received the sympathy, patronage, and active support of his great son, our most gracious King, who is working in so many directions for the welfare and happiness of our race.

There is one further point I must touch upon. In the few remarks which I have had the honour to make to you, I have endeavoured, however imperfectly, to embody in words certain thoughts which bear upon a great subject. I thank you for the patience with which you have heard me. Whether I have produced the effect I desire I know not, but $I$ know this, that even if I had the tongue of men and angeis, no words of mine could have been so apt, so expressive as the magnificent deed of Mr. Otto Beit recorded in to-das's newspapers. It is impossible for me to pass this over in silence, so closely is it connected with the subject of my address. There are two ways of manifesting thought, by word and by action. Mr. Beit has chosen the latter and far more effective way. We can only express our respectful admiration and gratitude for his generosity, ard our thankfulness that a man should exist anong us with the power, the insight, and the true humanity to do such a splendid deed.

\section{THE NEW DEPARTMENT OF BOTANY AT} UNIVERSITY COLLEGE, LONDON.

$\mathrm{N}$ Friday, December $\mathrm{I} 7$, the new botanical laboratories at University College, London, were formally opened io Dr. D. H. Scott, F.R.S., the Vice-Chancellor of the University of London (Prof. M. J. M. Hill, F.R.S.) presiding. Dr. Scott, in the course of a very interesting address, said that botany has been more fortunate in that college than in many others of more modern origin, for the subject has always been recognised from the foundation of the college as an independent science co-equal with her sisters. In the long period from $18_{2} 8$ to the present lime there have only been three appointments to the chair, viz. Profs. Lindley and Daniel Oliver, and the present occupant, Prof. F. W. Oliver. After giving an outline of the history of the department and of his own connection with it, Dr. Scott spoke of the various branches comprised in the subject. Systematic botany is the oldest branch, but it never can become old-fashioned. It is not needed less now than a century ago. At one time there was a tendency to neglect it somewhat in favour of the study of the structure and functions of some few plants which have been favoured with selection as types. Now the pendulum has swung the other way, and its importance is fairly recognised in teaching. It would be disastrous if systematic botany fell into neglect, and it would be peculiarly discreditable to English people, because systematic botany is specially a glory of this country.

Referring to the Hookers, Bentham, C. B. Clarke, and Daniel Oliver, Dr. Scott said it would appear to be a characteristic that the ablest minds have been attracted towards systematic botany. Comparative anatomy, he said, is now pressed into the same service as systematic botany. Comparative anatomy is particularly a study of the modern English school. These two branches are now subservient to questions of evolution, the search for relationships having become identified with the attempt to 